MedieKultur | Journal of media and communication research | ISSN 1901-9726

Article - Classics section

\title{
Framing: \\ Introduktion til et begreb og en klassisk tekst
}

\author{
Stig Hjarvard
}

MedieKultur 2015, 58, 104-114

Published by SMID | Society of Media researchers In Denmark | www.smid.dk The online version of this text can be found open access at www.mediekultur.dk

I denne introduktion til Robert Entmans artikel om framing fra 1993 prosenteres framing-begrebet og dets anvendelse i medie- og kommunikationsforskningen. Begrebets forhistorie inden for psykologisk og sociologisk forskning skitseres, ligesom den videre anvendelse og udvikling af begrebet hos Robert Entman og blandt andre medieforskere gennemgås og diskuteres. Senere teoretiske bidrag har iscer forsøgt at pracisere, hvordan framing indgår i de sociale og kommunikative processer, der former meningsdannelsen i samfundet. Til forskel fra konkurrerende og mere vidtrakkende teorier som semiotik og diskursanalyse, der også anvendes som afscet for analyse af medietekster, er teori om framing at opfatte som 'middle-range teori'.

\section{Indledning}

Med sin artikel "Framing: Til afklaring af et spredt paradigme" fra 1993 i Journal of Communication fik den amerikanske professor Robert M. Entman skabt et vigtigt teoretisk afsæt for at bruge framing-begrebet i medie- og kommunikationsforskningen. Begrebet har især vundet udbredelse inden for analyse af politisk kommunikation og journalistisk nyhedsformidling, men har også vist sig brugbart inden for andre genrer. Artiklens fortjeneste er, at den formår at definere framing på en kort og koncis måde og samtidig placere begrebet $\mathrm{i}$ en bredere kommunikationsmæssig kontekst. 
Ifølge Robert Entmans artikel består framing grundlæggende i udvelgelse af elementer fra erfaringsverdenen og fremhæevning af disse i en tekst, og denne framing bidrager til fire betydningsmæssige funktioner: en bestemt definition af problemet, en fortolkning af årsager, en moralsk evaluering og en anbefaling af, hvordan problemet skal behandles. Ikke alle fire betydningsmæssige funktioner behøver at være til stede i den enkelte frame, og de kan hver især være mere eller mindre eksplicitte i teksten. Denne definition har gjort det lettere at anvende framing-begrebet $i$ konkrete tekstanalyser, idet man har kunnet lede efter bestemte aspekter, der tilsammen konstituerer en frame.

I sin artikel gør Robert Entman det samtidig klart, at frames ikke kun eksisterer i konkrete (medie)tekster, men findes i alle dele af den samlede kommunikationsproces: afsenderen, teksten, modtageren og kulturen som helhed. Frames produceres af en konkret afsender under indflydelse af vedkommendes mentale fortolkningsskemaer, og tekstens frames danner afsæt for modtagerens forståelse af teksten, men også her er modtagerens forudforståelser vigtige for, hvorvidt tekstens frames udøver indflydelse på modtagerens meningsdannelse. Ved at inddrage det kulturelle niveau peger Robert Entman på, at man ikke kan forstå meningsdannelsen som proces ved alene at inddrage det enkelte og konkrete kommunikationskredsløb bestående af afsender, tekst og modtager, men må forstå meningsdannelsen i forhold til de frames, der allerede har vundet hævd inden for en given kultur eller en social gruppering, eksempelvis politiske eliter eller journalister. Hvordan den bredere meningsdannelse som proces foregår, kan framing-begrebet ikke i selv belyse, men det kan indgå som et centralt element i en bredere teori om dette, eksempelvis agendasetting teori (McCombs, 2004).

Inden for medieforskningen har framing-begrebet især vist sig nyttigt til at belyse, hvordan journalistiske fakta-tekster som nyheder og reportager ikke blot rapporterer om virkeligheden, men rummer en række betydningsmæssige valg, der tilskriver mening til begivenheder og afspejler aktørers interesser i disse ( $\mathrm{fx}$ bestemte aktørers interesse $\mathrm{i}$ at definere et problem som økonomisk og ikke økologisk). Samtidig bygger begrebet på en antagelse om, at framingen tager afsæt i virkelige erfaringer (subjektive som objektive), hvorudfra der foregår en udvælgelse og fremhævning af visse erfaringselementer - og dermed også en udeladelse og nedtoning af andre elementer. Framing-begrebet kan også anvendes til at belyse betydningsdannelse i fiktionstekster, eksempelvis i en komparativ analyse af forskellige films framing af en bestemt problematik; men framing-begrebet har sin kritiske brod $i$ analysen af fakta-tekster, da det kan demonstrere, hvordan fremstillingen af virkeligheden ikke er neutral, men altid beror på en række valg med konsekvenser for, hvordan vi overhovedet kommer til at forstå denne virkelighed.

I sin artikel argumenterer Robert Entman også for, at udviklingen af framing-begrebet til et mere konsistent begreb er et led $i$ at styrke medie- og kommunikationsforskningens generelle teoretiske stringens. Medie- og kommunikationsforskningen har ifølge Robert Entman potentiale til at udvikle sig til en overdisciplin for human- og samfundsvidenskaberne ved at syntetisere begreber, der finder spredt anvendelse i flere andre discipliner, men 
uden at have en fælles teoretisk ramme. Denne ambition afspejler til dels, at medie- og kommunikationsforskningen var en relativt ung disciplin på det pågældende tidspunkt, men behovet for at oparbejde stringente medie- og kommunikationsbegreber med relevans for andre fagfelter er ikke blevet mindre, siden Robert Entman udgav sin artikel i 1993. I takt med medialiseringen af stadig flere kultur- og samfundsinstitutioner (fx skoler, museer og sundhedsvæsen) kommer andre forskningsfelter i stigende grad til at interessere sig for, hvordan medier og kommunikation spiller en rolle inden for deres respektive felter. Det giver medie- og kommunikationsforskningen øget mulighed for at udvikle teorier og begreber, der kan have forskningsmæssig relevans for flere fagfelter (Hjarvard, 2012).

\section{Rammebegrebets rødder}

Robert Entman peger på framing som et eksempel på "spredt begrebsliggørelse"; begrebet har mange rødder og finder anvendelse flere steder. I sin korte artikel kommer han dog ikke nærmere ind på, hvorfra begrebet stammer, eller hvilke forskelle, der findes i brugen af framing i forskellige discipliner. Man kan dog skelne mellem en psykologisk og en sociologisk tilgang til begrebet (Scheufele \& Lyengar, 2014), om end grænsen mellem disse i nogle tilfælde er vanskelig at opretholde. Socialantropologen Gregory Bateson (1955) forsøgte som en af de første at afgrænse en psykologisk forståelse af framing; han diskuterede det $\mathrm{i}$ en artikel om, hvordan framingen af 'leg' som leg og ikke alvor beror på en gensidig kommunikation om en bestemt forståelse af interaktionens karakter. I hans afgrænsning af begrebet indgår bl.a., at en framing inkluderer og ekskluderer nogle betydningselementer, ligesom en frame udgør en præmis for forståelse af interaktionen og dermed også udgør en metakommunikation omkring, hvordan relationen mellem de kommunikerende parter skal forstås.

Et andet vigtigt psykologisk bidrag, som Robert Entman refererer til i sin artikel, blev leveret af Daniel Kahneman og Amos Tversky (1984), der gennem eksperimentelle studier påviste, hvordan en ændret framing af det selvsamme informationsindhold kan ændre på modtagerens evaluering af budskabet. Senere har Lakoff og Johnson (1999) ud fra et kognitionspsykologisk og lingvistisk udgangspunkt belyst, hvordan brug af bestemte metaforer skaber grundlag for en bestemt framing af vores forståelse af verden, og Lakoff $(2004,2013)$ har argumenteret for, at denne kognitionspsykologiske indsigt kan bruges som et led $\mathrm{i}$ en bevidst strategi for at frame politiske spørgsmål. Ottati m.fl. (2014) har ud fra et sådant perspektiv udviklet en 'metaforisk framing-model', der bl.a. skal underbygge, hvordan metaforisk sprogbrug kan frame modtagerens motivation og evne til at forstå et politisk budskab.

Inden for det sociologiske felt er Erving Goffmans studier af social interaktion en tidlig inspirationskilde til forstålse af framing-begrebet. I bogen Frame Analysis: An Essay on the Organization of Experience fra 1974 viser han, hvordan frames guider deltagernes definition af en situation og dermed skaber grundlag for, hvad der opfattes som passende og upassende handlinger (se også Jacobsen \& Kristiansen, 2002). Rammer er ikke kun et produkt af deltagernes frivillige fortolkning af situationen, men socialt udbredte, hvorfor de også 
udøver en styrende funktion på deltagerne. De sociale rammer udgør en form for matrice, hvorigennem en situation bliver meningsfuld for deltagerne, hvilket ligger i tråd med Goffmans generelle pointe om, at situationens karakter har forrang frem for deltagerne: "ikke mænd og deres øjeblikke, men snarere øjeblikke og deres mænd" (Goffman, 1967, p. 3).

Gaye Tuchmans (1978) analyse af nyhedsredaktioners arbejdsrutiner var et væsentlig bidrag til at føre framing-begrebet ind i den tidlige medie- og kommunikationsforskning. Hun kombinerede Goffmans mikro-sociologiske analyse med et organisationsanalytisk perspektiv for at belyse, hvordan journalistik som institutionaliseret praksis bidrager til at konstruere vores sociale virkelighed (Berger \& Luckmann, 1967). Hos Tuchman har framing en dobbelt karakter; som en institutionaliseret praksis skaber selve nyhedsformidlingen et bestemt blik på verden, og i kraft af journalisternes søgen efter konkrete vinkler på deres historier kommer de til at frame begivenheder på bestemte måder.

Todd Gitlin (1980) brugte framing-begrebet til at belyse, hvilken rolle nyhedsmediernes dækning af studenteroprør og det nye venstre i USA i 1960'erne spillede i den politiske proces. Her kommer han også med en karakteristik af framing, der på flere måder foregriber Entmans definition. Ifølge Gitlin (1980, p. 7) "er medieframes vedholdende mønstre af kognition, fortolkning og præsentation, af selektion, fremhævning og udeladelse, gennem hvilke symbolarbejdere rutinemæssigt organiserer diskurs, enten visuelt eller verbalt". I en dansk sammenhæng har framing-begrebet især været anvendt til at belyse politisk kommunikation og nyhedsmediernes dækning af politiske spørgsmål. Eksempelvis har Lund (2004) belyst, hvordan framing sammen med priming indgår i politikeres strategiske kommunikation, herunder spin, og Pedersen (2014) har analyseret nyhedsmediernes dækning af valgkampen i 2011 i forhold til, om framingen har fremhævet den politiske substans eller politiske proces. Hjarvard og Kristensen (2014) har kombineret en kvantitativ og kvalitativ analysemetode til at belyse, hvordan framingen af krigene i Afghanistan, Irak og Libyen på landsdækkende avisers lederplads har lighedspunkter med de politiske eliters framing af krigene.

\section{Entman og eliternes definitionsmagt}

Robert M. Entman er professor ved The George Washington University og forsker i samspillet mellem medier, politik og offentlig opinionsdannelse. Hans tilgang til framing-begrebet er fortrinsvis sociologisk og samfundsvidenskabelig og kun i beskeden grad psykologisk. Hans forskning har lige fra begyndelsen været præget af en kritisk indstilling til de måder, hvorpå både nyhedsmedier og den politiske elite påvirker den offentlige meningsdannelse, og framing-begrebet har i hans forskning været anvendt til at påvise, hvordan framing indgår i politisk og social magtudøvelse. I bogen Projections of Power: Framing News, Public Opinion, and U. S. Foreign Policy fra 2004 viser han gennem en række detaljerede analyser, hvordan amerikanske nyhedsmedier er under indflydelse af den framing, som det politiske establishment giver af en række udenrigspolitiske spørgsmål. Eksempelvis demonstrerer en 
sammenlignende analyse af henholdsvis Sovjetunionens nedskydning af det sydkoreanske KAL 007 passagerfly i 1983 og USA's nedskydning af det iranske Iran Air Flight 655 i 1988, hvordan nyhedsmedierne i førstnævnte tilfælde fortrinsvis anlagde en frame, der beskrev nedskydningen som en krigerisk handling, mens de i det andet tilfælde understøttede en framing, der fortolkede nedskydningen som et ulykkeligt resultat af en teknisk fejl.

Robert Entmans ærinde har tillige været at diskutere, hvordan fraværet af alternative frames til at forstå politiske spørgsmål kan svække den politiske meningsdannelse og demokratiske deltagelse. Carole Bell og Robert Entman (2011) viser, hvordan tv-nyhedsmediernes framing af Bushs skattenedsættelser i 2001 og 2003 gjorde det vanskeligt for den almindelige borger at foretage en balanceret afvejning af fordele og ulemper. En dominerende framing af skattenedsættelserne som gunstig for den økonomiske udvikling blokerede for, at en vurdering af fordele og ulemper for den enkelte borger eller for samfundet som helhed, blev et fremtrædende spørgsmål; eksempelvis blev skattenedsættelsernes konsekvenser $\mathrm{i}$ form af øgede indkomstforskelle ikke en væsentlig frame at forholde sig til. Robert Entmans interesse for framing er ikke begrænset til nyhedsmedierne. I bogen The Black Image in the White Mind: Media and Race in America fra 2000 skrevet sammen med Andrew Rojecki inddrages også tv-underholdningsprogrammer og Hollywood-film i en analyse af, hvordan massemedierne bidrager til framingen af race og specielt den sorte befolkning i USA.

Som nævnt tidligere kan man ikke alene $\mathrm{i}$ kraft af framing-begrebet belyse meningsdannelsen i samfundet eller mellem nyhedsmedier og borgere. Her må en teoriramme, der placerer framingen inden for en bredere påvirkningsproces mellem forskellige sociale aktører, inddrages. Robert Entman selv har i forlængelse af andre forskeres teorier om politiske eliters betydning for medierne og den politiske proces (Bennett, 1990; Hallin, 1986; Robinson, 2001) udviklet den såkaldte 'cascading network activation' model. Den bærende idé i denne model er at belyse, hvordan politiske eliter og nyhedsmedier gennem forskellige netværk udbreder deres kommunikation og konkurrerer med hinanden i fortolkningen af politiske og øvrige begivenheder, og hvordan dette forløb både påvirker og selv påvirkes af den offentlige mening og den bredere kultur. De forskellige aktører indgår i hierarkiske forhold til hinanden, men har samtidig en vis autonomi. Kommunikationen og framingen vil derfor ofte strømme ('cascade') fra de politiske eliter til underliggende grupper (fra præsidenten til ledende politikere og videre til nyhedsmedier osv.), men der er en række feedback-loops, som indebærer, at også eliten kan komme under pres fra fx nyhedsmediernes framing af begivenheder.

Robert Entman har bl.a. brugt denne model til at belyse, hvor vanskeligt det har været for nyhedsmedierne at udfordre den amerikanske regerings framing af terrorangrebet på USA den 11. september 2001 (Entman, 2003), og hvordan mediernes framing af skandaler omkring præsidentembedet kan bidrage til at få disse til at vokse eller blive dysset ned (Entman, 2012). Generelt peger Robert Entmans analyser på, at eliterne besidder en betydelig definitionsmagt til at frame begivenheder og politiske initiativer på bestemte måder, men hans mange konkrete analyser viser også, at nyhedsmedier og andre aktører under 
givne omstændigheder kan etablere modgående frames til alternativ forståelse af begivenhedernes årsager og konsekvenser.

\section{Kritik og videreudvikling af begrebet}

Framing-begrebet har gennem det sidste par årtier vundet betydeligt indpas i både medieforskningen og flere andre forskningsområder som fx politisk kommunikation, og her er det ofte den sociologiske aftapning af framing-begrebet, der har fundet anvendelse. I lyset af begrebets popularitet har Scheufele og Lyengar (2014) advaret mod en udvanding af framing-begrebet, hvad de især synes har fundet sted inden for den sociologiske aftapning af framing-forskningen. Som afsæt for deres kritik skelner de mellem en snæver, psykologisk 'ækvivalens-framing' og en bred, sociologisk 'fremhævelses-framing', som de opfatter Entman som en eksponent for. De er selv tilhængere af den snævre framing-opfattelse, idet den alene opfatter framing som den ændrede fremstilling af det samme informationsindhold (informationen er netop ækvivalent, tilsvarende, men blot framet forskelligt), mens det bredere framing-begreb undertiden også ser på, hvordan framing af delvist forskelligt informationsindhold ( $\mathrm{fx}$ brug af en økonomi-framing vs. en økologi-framing $\mathrm{i}$ en valgkamp) konkurrerer om opmærksomheden. Men herved forveksler den sociologiske framing-forskning 'billedrammen' med 'billedet', mener Scheufele og Lyengar og fortsætter polemisk: "Uheldigvis har mange forskere inden for politisk kommunikation studeret malerier snarere end rammer inden for de sidste to årtier. Og ikke overraskende finder de, at publikum ganske rigtigt reagerer anderledes på en Gauguin, end de ville gøre over for en Matisse" (Scheufele \& Lyengar, 2014, p. 6). Ved at holde fast i den snævre ækvivalensframing vil man ifølge dem i højere grad kunne sikre, at en måling af ændring i modtagerens holdning kan tilbageføres til forskelle i framing. Et udvandet framing-begreb vil ikke gøre det muligt at skelne mellem, hvad der er en effekt af framing, og hvad der eksempelvis er agenda-setting-effekter.

Scheufele og Lyengars (2014) kritik er relevant, da det er vigtigt, at en frame ikke kommer til at betyde hvad som helst og forveksles med andre, deskriptive indholdskategorier som fx emne eller tema. Der er heller ikke tvivl om, at en snæver forståelse af framing er ønskværdig, hvis man ønsker at kunne skelne entydigt mellem, hvorvidt accepten af en teksts dominerende frame hos publikum alene skyldes framingen og ikke andre informationselementer. Problemet er, som de også selv antyder, at den snævre framing-opfattelse praktisk talt kun kan operationaliseres under eksperimentelle vilkår og ikke i den virkelige verden. Det er uhyre sjældent, at det helt samme informationsindhold blot frames forskelligt; den sociologiske forståelse af framing hos Robert Entman har netop som definitorisk træk, at den udvælger visse erfaringselementer og fravælger andre, hvorfor tekster med konkurrerende frames ikke vil have nøjagtigt samme informationsindhold. Sagt på en anden måde kan en teksts informationsindhold ikke ses adskilt fra den framing-proces, som teksten er blevet til under. Scheufele og Lyengars snævre framing-begreb har en eksperimentel fordel 
ved at muliggøre en kunstig separation af informationsindhold og framing, men det mangler til gengæld det sociologiske begrebs dynamiske aspekt, hvor en frame ikke er en udvendig side af tekstens informationsindhold, men en integreret del af tekstens betydning og et spor af tekstens tilblivelsesproces.

I videreudviklingen af framing-begrebet er den processuelle dimension forsøgt indfanget gennem en skelnen mellem 'frame-opbygning', 'frame-fastlæggelse' og 'konsekvenser af framing' (Scheufele, 2000; Vreese, 2005). Hvis analysen gælder framing af nyheder, vil en analyse af 'frame-opbygning' se på de interne faktorer på en nyhedsredaktion (organisationskultur, professionelle normer og rutiner m.m.) samt eksterne faktorer som interaktionen med kilder (politiske aktører, interesseorganisationer m.m.); den endelige framing er et resultat af sådanne konkurrerende hensyn, herunder de frames som andre aktører prøver at få journalister til at overtage. Analysen af 'frame-fastlæggelsen' ser på receptionen af teksten, dvs. i hvilket omfang og hvordan nyhedstekstens frames overtages eller modificeres i mødet med modtagerens forudgående forståelser af det pågældende fænomen. 'Konsekvenserne af framing' vedrører den holdnings- og adfærdsmæssige forandring (eller bestyrkelse af eksisterende holdninger og adfærd), som en nyhedsframing kan udvirke.

Som tidligere nævnt må en analyse af framingens betydning for meningsdannelsen medtænke anden teori om, hvordan individuel og kollektiv opinionsdannelse finder sted. I den sammenhæng er det interessant, at dagsordensteorien har forsøgt at medreflektere, hvordan framing skal forstås i relation til den gensidige proces, hvor forskellige dagsordener - typisk beslutningstageres, nyhedsmediers og befolkningens dagsorden - gensidigt påvirker hinanden. Den klassiske dagsordensteori havde som hovedtese, at medierne ikke havde indflydelse på befolkningens konkrete synspunkter for eller imod et givent emne, men alene havde indflydelse på, hvad borgerne opfattede som vigtigt at diskutere. Som følge heraf fokuserede man på, hvilke emner og temaer der blev tildelt opmærksomhed $i$ mediernes dagsorden for derved at kunne undersøge, hvorvidt disse emner og temaer også kom til at rangere højt på befolkningens dagsorden. Til gengæld fokuserede man ikke på, hvordan medierne talte om de emner og temaer, man registrerede.

I nyere dagsordensteori har man forladt denne simple model til fordel for en tre-leddet model, hvor man også interesserer sig for organiseringen af mening i form af 'overbevisende argumenter' (Ghanem, 1997; McCombs, 2004). I den sammenhæng opfattes framing som afgørende for den såkaldte 'dagsordenssætning af egenskaber'. Den traditionelle dagsordenssætning med overførsel af opmærksomhed på et emne fra en dagsorden til en anden udgør dagsordenssætningens første niveau, mens fremhævningen af bestemte egenskaber ved et emne, dvs. framingen af emnet, udgør dagsordenssætningens andet niveau. Framingen skaber grundlag for det overbevisende argument, der som det tredje niveau i processen medfører, at både emne og argument får en mere fremtrædende plads på dagsordenen. Scheufele og Tewksbury (2007) er dog kritiske over for, hvorvidt man kan integrere framing og dagsordenssætning på denne måde. 
I den faktiske analyse af frames kan man gå både induktivt og deduktivt til værks; dvs. man kan vælge at identificere specifikke frames med afsæt i de konkrete tekster, der skal analyseres, eller man kan vælge at tage afsæt $\mathrm{i}$ allerede eksisterende og udbredte frames om givne emnefelter. Hvad der er mest passende at gøre, afhænger af de konkrete forskningsspørgsmål for analysen, men i alle tilfælde er det afgørende, at man er i stand til at forankre sin identifikation af frames i konkrete tekstlige iagttagelser. Vreese $(2002,2005)$ foretager en grundlæggende skelnen mellem 'emne-specifikke' frames og 'generiske' frames, dvs. mellem frames, der er karakteristiske for et bestemt emnefelt, $f x$ udlændinge- og flygtningepolitik, og frames, der går på tværs af emneområder og tillader sammenligning på tværs af disse. I sidstnævinte tilfælde kan det fx være en sammenligning mellem brug af en 'konflikt-framing' og en 'løsnings-framing' i forhold til forskellige politiske emner.

\section{Framing: Et bidrag til middle-range teori}

Framing-begrebet adresserer en række af de samme spørgsmål, som også er centrale inden for andre teoridannelser om teksters betydning og meningsdannelse, eksempelvis semiotikken og diskursteorien. Disse teorier har alle som et fælles anliggende at belyse, hvordan teksters betydning både er et resultat af og udvirker indflydelse på menneskers sproglige og sociale interaktion, herunder hvordan teksterne indgår i (re)produktion af herskende opfattelser af kultur og samfund. Det er således også værd at bemærke lighedspunkterne mellem Robert Entmans fremstilling af framingens fire steder (afsender, tekst, modtager og kultur) og Stuart Halls (1973) indkodning-afkodningsmodel, hvor begrebet 'framework' også spiller en vigtig rolle.

Hvor semiotikken (Barthes, 1970; Greimas, 1966) og diskursanalysen (Dijk, 2009; Fairclough, 2001; Laclau \& Mouffe, 2002) har et europæisk udspring inden for sprogvidenskab og kritisk teori, er framing-begrebet i højere grad af amerikansk afstamning og tager afsæt i psykologisk og mainstream samfundsvidenskabelig teori. Hos Robert Entman har begrebet tydeligvis også en kritisk dimension, idet det netop har til formål at afdække, hvordan tekster ikke blot er neutrale gengivelser af virkeligheden, men præget af bestemte aktørers ønske om at udøve indflydelse på opinionsdannelsen; men framing-begrebet er ikke $\mathrm{i}$ samme grad forankret i en kritisk teoridannelse, der forudsætter en bestemt opfattelse af kultur og samfund endsige en særlig politisk dagsorden. I modsætning hertil har i hvert fald visse aftapninger af semiotikken og diskursanalysen karakter af 'grand theory', der forstår teksters kommunikative karakter i lyset af en generel og kritisk kultur- og samfundsteori.

Den teoriudvikling, som framing-begrebet bidrager til, kan derfor med Merton's betegnelse (1957) kaldes en 'middle-range teori'. Med denne betegnelse peger Merton på, at imellem den helt lokale systematisering af iagttagelser på mikro-niveau på den ene side og de generelle, globale teorier på den anden side, finder vi en gruppe af teorier, som prøver at skabe begrebsmæssig forståelse på et mellemniveau, dvs. et mere afgrænset og veldefineret felt. 'Middle-range teori' understøtter begrebsudvikling til forståelse af systematiske 
sammenhænge inden for en given samfundsmæssig sammenhæng, samtidig med at man føler sig forpligtet til at konsolidere begrebsdannelsen i empiriske studier. Sammenlignet hermed er semiotikken og diskursanalysen generelle eller globale teorier. Der er fordele og ulemper ved både 'middle-range teorier' og globale teorier. Globale teorier har den fordel, at de tilbyder en mere omfattende teoretisk ramme, hvor en lang række begreber har en veldefineret betydning i forhold til hinanden, og de har ofte som ambition at levere en sammenhængende forklaring på flere forskellige fænomener på tværs af tid og sted. I lyset af dette kan 'middle-range teorier' se mindre ambitiøse ud og have problemer med at fa begreber fra én sammenhæng til at fungere sammen med begreber fra en anden teoretisk kontekst. Til gengæld har globale teorier ofte det problem, at de i praksis har svært ved at finde empirisk belæg for deres ofte meget vidtrækkende hypoteser, ligesom de kan savne sensitivitet og forklaringskraft over for specifikke kontekster.

Framing-begrebet har sin styrke $\mathrm{i}$, at det understøtter en præcis og systematisk analyse af tekster og deres mulige samspil med meningsdannelsen. Det forudsætter ikke nødvendigvis en global teori om kultur og samfund, men kan bidrage til at opbygge 'middle-range teorier' om $\mathrm{fx}$ samspillet mellem politiske eliter og meningsdannelsen eller journalisters selektive vinkling af nyhedshistorier. Hvor visse aftapninger af diskursteori (fx Laclau \& Mouffe, 2002) forudsætter en generel teori om magt, hegemoni og konflikter i samfundet, behøver man ved brug af framing-begrebet ikke nødvendigvis forlods at acceptere bestemte, universelle forklaringsparadigmer. Denne forskel mellem framing- og diskursteori har givetvis haft betydning for, at framing-begrebet også har vundet indpas inden for mainstream medieforskning og statsvidenskab i USA, hvor man typisk opfatter europæisk, kritisk teori med en vis skepsis. Det er samtidig værd at understrege, at framing-begrebet ikke udelukker en kobling til fx semiotik eller kritisk teori; der er som nævnt en række ligheder mellem Entmans forståelse af framing og de opfattelser af teksters ideologiske funktioner, man finder i semiotik og kritisk teori.

Med sin tekst fra 1993 fik Robert Entman etableret et væsentligt grundlag til forståelsen af framing, som har inspireret mange i medie- og kommunikationsforskningen til at arbejde videre med begrebet, såvel empirisk som teoretisk. Der er fortsat behov for en videreudvikling af begrebet for at forstå framingens nærmere rolle i meningsdannelsen, herunder empiriske studier til at underbygge hypoteser om dette. Robert Entman har med sit fortsatte arbejde inden for dette felt bidraget til en sådan videreudvikling, især hvad angår samspillet mellem politiske eliter, medierne og den politiske opinion.

\section{Referencer}

Barthes, R. (1996 [1970]). Mytologier. København: Gyldendal.

Bateson, G. (2006 [1955]). A Theory of Play and Fantasy. In K. Salen \& Eric Zimmerman (eds.), The Game Design Reader (pp. 314-329). Cambridge, Mass.: MIT Press. 
Bell, C.V. \& Entman, R.M. (2011). The Media's Role in America's Exceptional Politics of Inequality: Framing the Bush Tax Cuts of 2001 and 2003. The International Journal of Press/Politics, 16(4), 548-572.

Bennett, W.L. (1990).Toward a Theory of Press-State Relations in the United States. Journal of Communication , 40(2), 103-125.

Berger, P. \& Luckmann, T. (1967). The Social Construction of Reality. New York: Doubleday-Anchor.

Dijk, T.A. van (2009). News, Discourse and Ideology. In K. Wahl-Jørgensen \& T. Hanitzsch (eds.), The Handbook of Journalism Studies (pp. 191-204). New York and London: Routledge.

Entman R.M. (1993). Framing: Toward Clarification of a Fractured Paradigm. Journal of Communication, 43(4), 51-58. Konsulteret 8. januar 2015, http://onlinelibrary.wiley.com/doi/10.1111/j.1460-2466.1993. tb01304.x/pdf.

Entman, R.M. \& Rojecki, A. (2000). The Black Image in the White Mind: Media and Race in America. Chicago: University of Chicago Press.

Entman, R.M. (2003). Cascading Activation: Contesting the White House's Frame After 9/11. Political Communication, 20, 415-432. Konsulteret 8. januar 2015: http://www.tandfonline.com/doi/ $\mathrm{pdf} / 10.1080 / 10584600390244176$.

Entman, R.M. (2004). Projections of Power: Framing News, Public Opinion and U.S. Foreign Policy. Chicago: The University of Chicago Press.

Entman, R.M. (2012). Scandal and Silence. Media Responses to Presidential Misconduct. Cambridge: Polity.

Fairclough, N. (2001) Media Discourse. London: Arnold.

Ghanem, S. (1997). Filling in the tapestry: The second level of agenda-setting. In M. McCombs, D.L. Shaw \& D. Weaver (eds.), Communication and Democracy: Exploring the Intellectual Frontiers in Agenda-Setting Theory (pp. 3-14). Mahwah, N.J.: Lawrence Erlbaum Associates.

Gitlin, Todd (1980). The Whole World is Watching. Mass Media in the Making \& Unmaking of the New Left. Berkeley: University of California Press.

Goffman, E. (1967). Interaction Ritual. Harmondsworth: Penguin.

Goffman, E. (1974 [1986]). Frame Analysis: An Essay on the Organization of Experience. Cambridge, Mass.: Northeastern University Press.

Greimas, A.J. (1974 [1966]). Strukturel semantik. København: Borgen.

Hall, S. (1973) Encoding and Decoding in the Television Discourse. Stencilled Occasional Paper no. 7, Birmingham: CCCS.

Hallin D.C. (1986). The 'Uncensored War', the Media and Vietnam. New York: Oxford University Press.

Hjarvard, S. (2012). Doing the Right Thing. Media and Communication Studies in a Mediatized World. Nordicom-Information 34 (2), 27-34.

Hjarvard, S. \& Kristensen, N.N. (2014). When Media of a Small Nation Argue for War. Media, War \& Conflict, $7(1), 51-69$.

Jacobsen, M.H. \& Kristiansen, S. (2002). Erving Goffman. Sociologien om det elementæere livs sociale former. København: Hans Reitzels Forlag.

Laclau, E. \& Mouffe, C. (2002). Det radikale demokrati, diskursteoriens politiske perspektiv. Frederiksberg: Roskilde Universitetsforlag.

Lakoff, G. \& Johnson, M. (1999). Philosophy in the Flesh. The Embodied Mind and Its Challenge to Western Thought. New York: Basic Books.

Lakoff, G. (2004). Don't Think of an Elephant! How Democrats and Progressives Can Win: Know Your Values and Frame the Debate: The Essential Guide for Progressives. White River Junction, Vt.: Chelsea Green Publishing Company.

Lakoff, G. (2013). Obama Reframes Syria: Metaphor and War Revisited. Konsulteret 12. januar 2015, http:// georgelakoff.com/2013/09/06/obama-reframes-syria-metaphor-and-war-revisited. 
Lund, A. B. (2004). Niche Nursing Political Networks: Priming and Framing before Spinning. Modinet Working paper no. 9. Konsulteret 8. januar 2015, http://www.modinet.dk/pdf/WorkingPapers/No9_Niche_ Nursing_Political_Networks.pdf.

McCombs, M. (2004). Setting the Agenda. Cambridge: Polity.

Merton, R.K. (1957). Social Theory and Social Structure. Glencoe, IL: Free Press.

Ottati, V., Renstrom, R. \& Price, E. (2014). The Metaphoric Framing Model: Political Communication and Public Opinion. In M.J. Landau, M.D. Robinson \& B.P. Meier (eds.), The Power of Metaphor: Examining Its Influence on Social Life (pp. 179-202). Washington, DC: American Psychological Association.

Pedersen, R.T. (2014). Avisernes fokus og framing under valgkampen. In K.M. Hansen \& K. Kosiara-Pedersen (eds.), Folketingsvalgkampen 2011 i perspektiv (pp. 283-294). København: DJØF-forlaget.

Robinson, P. (2001). Theorizing the Influence of Media on World Politics: Models of Media Influence in Foreign Policy. European Journal of Communication, 16(4), 523-544.

Scheufele, D.A. (2000). Agenda-Setting, Priming, and Framing Revisited. Another look at cognitive effects of political communication. Mass Communication \& Society, 3, 297-316.

Scheufele, D. A. \& Lyengar, S. (2014). The State of Framing Research: A Call for New Directions. In K. Kenski \& K.H. Jamieson (eds.): The Oxford Handbook of Political Communication. Konsulteret 8. januar 2015, http://www.oxfordhandbooks.com/view/10.1093/oxfordhb/9780199793471.001.0001/oxfordhb9780199793471-e-47.

Scheufele, D.A. \& Tewksbury, D. (2007). Framing, Agenda Setting, and Priming: The Evolution of Three Media Effects Models. Journal of Communication, 57(1), 9-20. Konsulteret 8. januar 2015, http://onlinelibrary.wiley.com/doi/10.1111/j.0021-9916.2007.00326.x/pdf.

Tuchman, G. (1978). Making News. A Study in the Construction of Reality. New York: The Free Press.

Vreese, C.H. de (2002). Framing Europe: Television news and European integration. Amsterdam: Aksant Academic Publishers.

Vreese, C.H. de (2005). News framing: Theory and typology. Information Design Journal + Document Design, 13(1), 51-62.

Stig Hjarvard Ph.D., Professor Institut for Medier, Erkendelse og Formidling Københavns Universitet stig@hum.ku.dk 